\title{
Erikoiskasvien sekundääriaineet
}

\section{Sekundääriaineiden vaihtelu ja mahdollisuudet vaikuttaa niiden esiintymiseen viljelytekniikan avulla}

\author{
Marjo Keskitalo \\ Maa-ja elintarviketalouden tutkimuskeskus, Kasvinviljely ja biotekniikka, 31600 Jokioinen, \\ marjo.keskitalo@mtt.fi
}

Kasveissa muodostuvien aineenvaihduntatuotteiden monipuolisempi hyödyntäminen elintarvikkeissa ja non-food tuotteissa on yksi kasvintuotannon tulevaisuuden mahdollisuuksista. Eräs mielenkiintoinen aineenvaihduntaryhmä on sekundääriaineet. Nämä aineet poikkeavat primäärisistä metaboliatuotteista kuten valkuaisaineista, öljyistä ja sokereista monessa suhteessa. Sekundääriaineet eivät sisällä energiaa, ne esiintyvät pieninä pitoisuuksina ja lukumääräisesti niitä esiintyy kasvikunnassa vähintään nelin-viisinkertaisesti primäärisiin verrattuna.

Sekundääriaineiden erityisominaisuuksia ovat niiden lääkinnälliset kuten solujen hapettumista estävät vaikutukset ja mikrobien kasvua ehkäisevät ominaisuudet (Lucner 1990, Tringali 2000). Aineiden välillä on suuria eroja ja niiden vaikutusmekanismien ymmärtäminen on vasta aluillaan (Romagni et al. 2000). Tällä hetkellä sekundääriaineita hyödynnetään elintarvikkeissa mukaan lukien juomat, makeiset ja mausteet; lääkkeissä ja luontaistuotteissa; kosmetiikassa; kodin kemikaaleissa ja torjuntaaineissa. Sekundääriaineisiin liittyviä tutkimuksia on myös meneillään lukuisia. Tutkimusten erityispaino on viime aikona ollut siinä, miten sekundääriaineita voidaan hyödyntää funktionaalisissa elintarvikkeissa ja kasvinsuojelussa. Uusien tai paremmin ymmärrettyjen vaikutusmekanismien takia käyttökohteita saattaa löytyä tulevaisuudessa lisää. Sekundääriaineet voivat olla myös maun, tuoksun tai värin antajia, jolloin ominaisuutta voidaan käyttää sekä elintarvikkeissa että non-food tuotteissa.

Sekundääriaineiden käytön lisääntyessä tarvitaan tietoa siitä, miten ja kuinka paljon aineita kasveissa muodostuu, mitkä tekijät niihin vaikuttavat ja voidaanko viljelytekniikkaa optimoida sekundääriaineden kannalta edullisemmaksi. Tieto auttaa myös vähentämään sekundääriaineista aiheutuvia ei-toivottuja vaikutuksia kuten allergiaa. Maa- ja elintarviketalouden tutkimuskeskuksen Kasvintuotannon tutkimuksessa olemme tutkineet erikoiskasvien satofysiologiaa ja kasvien sisältämiä sekundääriaineita. Tarkoituksena on, että ymmärtäisimme paremmin aineiden muodostumista ja niihin vaikuttavia tekijöitä, jotta haluttuja komponentteja voitaisiin tuottaa mahdollisimman optimaalisesti.

Esitelmäni koostuu useasta eri tutkimuksesta, joissa on määritetty kuminan, tattarin, pellavan, sinapin ja värimorsingon sekundääriaineiden vaihteluita sekä mm. typpilannoituksen vaikutusta pitoisuuksiin (Keskitalo et al. 2000). Tutkimuksissa on käsitelty neljää eri sekundääriaineryhmää, jotka ovat terpeenit (kumina), fenoliset yhdisteet (tattarin flavonoidit ja pellavan lignaanit ja fenoliset hapot); glukosinolaatit (sinappi) ja indigot (värimorsinko). Kyseiset erikoiskasvit on valittu mukaan, koska niiden sisältämät sekundääriaineet mahdollisesti vaikuttavat ihmisen terveyteen positiivisesti (Hietaniemi et al. 1999), toimivat torjunta-aineena (Hannukkala et al. 2001) tai tuottavat väriaineita.

\section{Lähteet}

-Hannukkala, A., Keskitalo, M., Laamanen, J. \& Rastas, M. (2001). Comtrol of potato late blight with caraway and dill extracts. Potato late blight workshop, Edinburgh, UK, 26-30 September 2001.

-Hietaniemi, V., Keskitalo, M., Korhonen, H., Kumpulainen, J., Pihlava, J.-M., Ryhänen, E.-L., Tiilikkala, K. (1999). Plant derived biomolecules - prominent ingredients for functional foods. Innovations in food technology 4:23-26.

-Keskitalo, M., Linnala, M. \& Pihlava, J.-M. (2000). Production of plant biomolecules for food in nordic growth conditions. In: European Conference on Nutritional Enhancement of Plant Foods : Neodiet; Norwich Research Park, September 2000. 1 p. (Supported under the EU FAIR programme (FAIR-CT97-3052).

-Lucner, M. 1990. Secondary metabolism in microorganisms, plants, and animals. 563 p. ISBN 3-540-50287-4. -Romagni, J.,G, Duke, S.,O \& Dayan, F.,E 2000. Inhibition of plant asparagine synthetase by monoterpene cineoles. Plant Physiology 123: 725-732.

-Tringali, C. 2000. Bioactive compounds from natural sources. 693 p. ISBN 0-7484-0890-8. 